\title{
Predicted influence of overhead transmission lines on land-use transfer: A case study on landscape and famous scenery
}

\author{
Xi Chen ${ }^{1}$, Ying Gao ${ }^{2 *}$, Fengjiao Peng ${ }^{2}$, Cuicui Hang ${ }^{1}$, Yong Cai ${ }^{3}$ and Bo $\mathrm{Wang}^{4}$ \\ ${ }^{1}$ Economic Research Institute of State Grid Hubei Electric Power Company, Wuhan 430077, Hubei, China; \\ ${ }^{2}$ Central Southern China Electric Power Design Institute co., ltd. of China Power Engineering Consulting Group, Wuhan 430074, Hubei, \\ China; \\ ${ }^{3}$ State Grid Hubei Electric Power co., ltd, Wuhan 430077, Hubei, China; \\ ${ }^{4}$ Hubei Central China Technology Development of Electric Power co., ltd, Wuhan 430074, Hubei, China.
}

\begin{abstract}
Taking Baihetan-Jiangsu $\pm 800 \mathrm{kV}$ UHVDC power transmission project as an example, the influence of tower foundation on land-use types and functions were predicted using ArcGIS platform and eCognition Developer. Through the construction of land-use transfer matrix analysis, the change of land-use transfer situation and structure were discussed. Our results showed that the forest transfer intensities $\left(R_{T}\right)$ of Tangya River Scenic spot and Three Gorges Scenic area were 0.64 and 1.49 respectively, the $R_{T}$ of bushes and grasses in Tangya River Scenic spot and Three Gorges Scenic area were 1.01 and 0.37. The $R_{T}$ of forest, bushes and grasses were both not high. The permanent occupation area of project was all transferred into building land, the construction land dynamics degrees $\left(K_{T}\right)$ of Tangya River Scenic spot and Three Gorges Scenic area were $+0.40 \%$ and $+0.031 \%$ respectively, which were both low. Thus we drew a conclusion that the project construction would have a slight impact on land use pattern and function and would not affect the overall ecological function and structure of landscape and famous scenery.
\end{abstract}

\section{Introduction}

With the development of economy, electricity consumption, the total load of regional power grid was on the rise. The expansion of power grid planning system can bring obvious social and economic benefits in energy development, industrial layout, load adjustment, system security and economic operation [1]. The future power grid would also realize the optimal allocation of resources by long distance, large capacity and crossregion [2]. Since the overhead transmission line was a linear project, it passed through a wide range of areas, and sometimes it was difficult to avoid the sensitive area completely. Currently, the ecological impact of overhead transmission lines in environmental impact assessment was mainly manifested in the permanent occupation of line base. The permanent occupation would lead to the loss of land use function and the transfer of land-use type in protected area [3].

The dynamic study of land-use and land-cover were a key and urgent subject [4]. In 1995, the International Geosphere and Biosphere Program (IGBP) and the Human Dimension Plan of global environmental change (HDP) jointly proposed a research plan named "Land-use and Land-cover Change (LUCC)". From then on, the study of land use change has become a foreword and hotspot research [5]. The land-use matrix can not only quantitate the structure characteristics of regional land- use change, but also can predict the direction of land-use type change. Recently, the land-use transfer matrix mainly focused on the net change of land-use type [6], without considering the spatial process and related attributes of the dynamic change. Thus most of study can not depict the spatial process of land-use change completely [7].

In this study, the net change, transfer intensities $\left(R_{T}\right)$ and the construction land dynamics degrees $\left(K_{T}\right)$ of landuse type were adopted to truly show the spatial process of land-use change [3]. Taking Baihetan-Jiangsu $\pm 800 \mathrm{kV}$ UHVDC power transmission project as an example, we predicted the influence of tower foundation on landscape and famous scenery. This project crossed the provincial scenic area of Tangya River and the Three Gorges of the Yangtze River, occupied permanent area in scenic area, which has typical representative.

Baihetan-Jiangsu $\pm 800 \mathrm{kV}$ UHVDC power transmission project was selected. This project started from xianfeng converter station in Liangshan prefecture, passed through Sichuang province, Chongqing City, Hubei Province, Anhui Province, Jiangsu Province, and ended at Changshu Nanyushan converter station in Suzhou, involving 5 provinces, 20 cities and 58 districts and counties. The total length of the path was about $2081.9 \mathrm{~km}$. Due to long conveying distance, urban planning, terrain 
Table 1 Details of Project

\begin{tabular}{|c|c|c|c|c|c|}
\hline Project & $\begin{array}{c}\text { Landscape } \\
\text { and famous } \\
\text { scenery }\end{array}$ & $\begin{array}{l}\text { Relative position } \\
\text { relation }\end{array}$ & $\begin{array}{l}\text { Evaluation } \\
\text { area } / \mathrm{hm}^{2}\end{array}$ & $\begin{array}{c}\text { Area of landscape } \\
\text { and famous scenery } \\
/ \mathrm{hm}^{2}\end{array}$ & Type of protected area \\
\hline \multirow{2}{*}{$\begin{array}{c}\text { Baihetan- } \\
\text { Jiangsu } \\
\pm 800 \mathrm{kV} \\
\text { UHVDC } \\
\text { power } \\
\text { transmission } \\
\text { project }\end{array}$} & $\begin{array}{l}\text { Tangya } \\
\text { River }\end{array}$ & $\begin{array}{l}\text { Crossed second-level } \\
\text { protection } 0.9 \mathrm{~km}, \\
\text { Crossed third-level } \\
\text { protection } 4.7 \mathrm{~km}, \\
\text { a total of } 10 \mathrm{bases} \\
\end{array}$ & about 2507 & 34910 & $\begin{array}{l}\text { Mainly to forest ecosystem } \\
\text { and farmland ecosystem }\end{array}$ \\
\hline & $\begin{array}{c}\text { Three } \\
\text { Gorges of } \\
\text { the Yangtze } \\
\text { River }\end{array}$ & $\begin{array}{l}\text { Crossed second-level } \\
\text { protection } 3.0 \mathrm{~km}, \\
\text { Crossed third-level } \\
\text { protection } 1.2 \mathrm{~km}, \\
\text { a total of } 7 \text { bases }\end{array}$ & about 3171 & 113300 & $\begin{array}{c}\text { Mainly to forest } \\
\text { ecosystem, farmland } \\
\text { ecosystem and wetland } \\
\text { ecosystem }\end{array}$ \\
\hline
\end{tabular}

(Note: according to the Technical Guidelines for Environmental Impact Assessment on Power Transmission and Transformation Engineering (HJ24-2014), the evaluation area in this study was the belt area within $1000 \mathrm{~m}$ on both sides outside the ground projection of the conducting wire.)

conditions and other restrictions, the line could not completely avoid sensitive areas, and finally crossed the provincial scenic area of Tangya River and Three Gorges of the Yangtze River in Hubei Province.

Baihetan-Jiangsu $\pm 800 \mathrm{kV}$ UHVDC power transmission project passed through Tangya River for three times, crossed the second-level protection area 0.8 $\mathrm{km}$ (without setting tower), the second-level protection area $0.1 \mathrm{~km}$, the third-level protection area $4.7 \mathrm{~km}$, setting up a total of 10 bases. On the other hand, this project passed through the Three Gorges of the Yangtze River, crossed the second-level protection area $3.0 \mathrm{~km}$, thirdlevel protection area $1.2 \mathrm{~km}$, also setting up a total of 7 bases. This study selected the area of cross section, estimating the permanent occupation area, constructing the land-use transfer matrix, finally predicting the influence of landscape and famous scenery on land-use [8]. Details were showed in Table 1.

\section{Method}

\subsection{Interpretation and calculation of land use types}

The high-resolution image was used as the source data and the image was calibrated, spliced and cut by using Arc GIS, then the type of land-use were divided into five categories, which were forest land, bushes and grasses land, cultivated land, water, building and other land [9]. Land-use data within the evaluation area were extracted by the method of human-computer interactive interpretation though eCognition8.0. The technology roadmap was shown in Figure1.

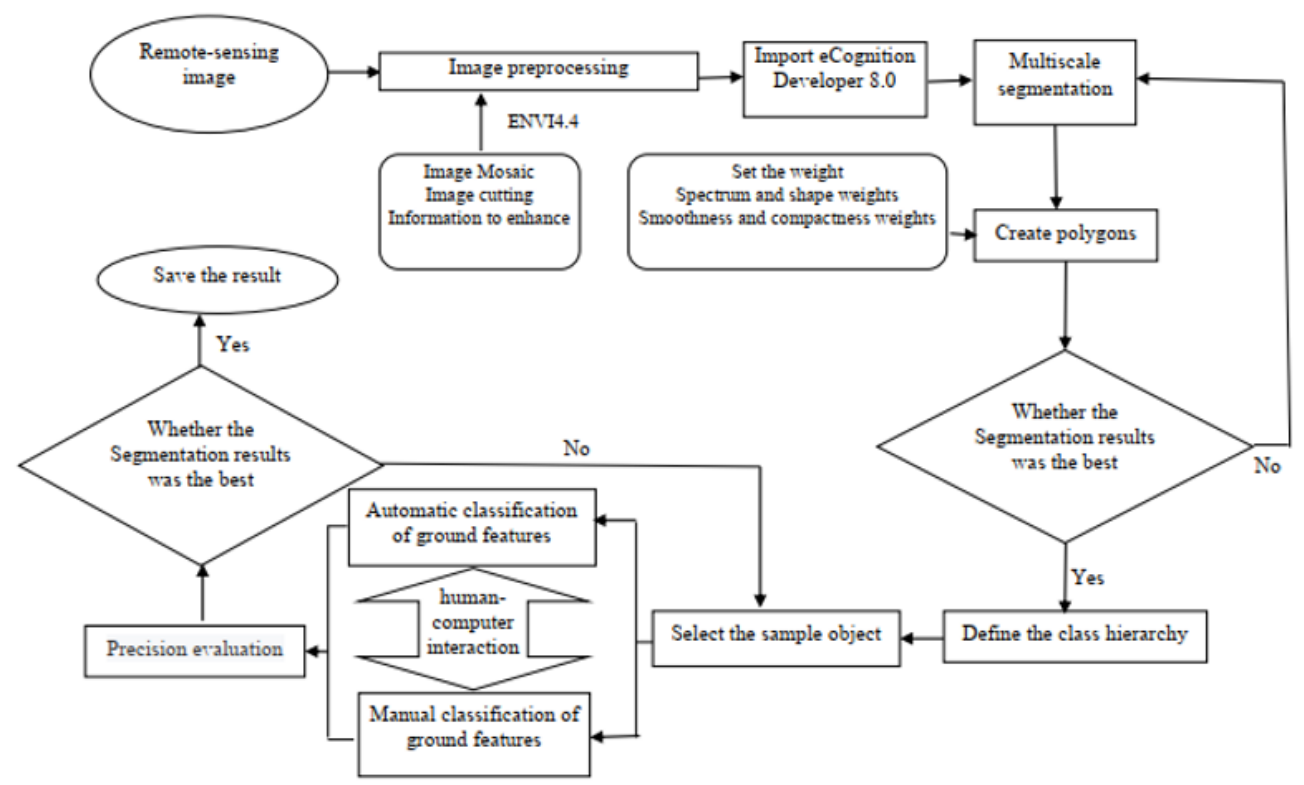

Figure1. Extraction and interpretation process of land-use remote sensing information 


\subsection{Calculation and construction of land-use transfer matrix}

Interpreted the land-use type data within the evaluation scope, then loaded into ArcGIS to obtain the type of land-use. According to the land-use type and the proposed base of tower in landscape and famous scenery, the land-use change situation after the completion of the project was estimated and the land-use area transfer matrix were constructed. The relevant indexes of landuse transfer were calculated as follows:

$$
K_{T}=\left(\mathrm{U}_{\mathrm{b}}-\mathrm{U}_{\mathrm{a}}\right) / \mathrm{U}_{\mathrm{a}} \times 1 / \mathrm{T} \times 100 \%
$$

$K_{T}$ represented a certain land-use dynamic attitude, $\mathrm{U}_{\mathrm{a}}$ and $\mathrm{U}_{\mathrm{b}}$ were the area of a certain land at the beginning and the end of the research respectively. $\mathrm{T}$ was the time of research. When the time was set as year, the value of $K_{T}$ was the annual change rate of a certain land-use type.

$$
R_{T}=\left(\triangle \mathrm{LU}_{\mathrm{i}} / \mathrm{LU}_{\mathrm{i}}\right) /\left(\triangle \mathrm{LU}_{0} / \triangle \mathrm{LU}_{0}\right)
$$

$R_{T}$ was the intensity of land-use conversion, $\triangle \mathrm{LU}_{\mathrm{i}}$ was the transferred area of certain $i$ land, $L_{i}$ was the land area of certain $i$ land at the initial period. $\triangle \mathrm{LU}_{0}$ was the total roll-out area of the evaluation area, $\mathrm{LU}_{0}$ was the total area of the initial evaluation area before the construction .

$K_{T}$ - the dynamic attitude of a certain land-use type, represented the quantitative change of a certain land-use type within a certain time in the research area, which can describe the speed of land-use change within a certain time, compare the regional difference and predict the trend of land-use change in the future.

$R_{T}$ - the intensity of land-use conversion, can describe the multiple relation between the conversion rate of certain land type and the whole land conversion rate quantitatively, compare the regional difference of landuse change, analyze and predict the dynamic structure of land-use transfer within a certain time. When the $R_{T}>1$, it indicated that the roll-out intensity of a certain type was higher than that of whole evaluation area, otherwise, the roll-out intensity was lower than the overall roll-out intensity. When the $R_{T}>5$, it was believed that the transfer intensity of a certain type land was significantly higher than that of the whole evaluation area [10-12].

\section{Results}

\subsection{Land-use transfer matrix of Tangya River Scenic spot}

The land-use transfer matrix result of Tangya River was shown in Table 2. The project was intended to occupy an area of $0.34 \mathrm{hm}^{2}$ permanently. Results showed that the land-use type of evaluation area in Tangya River Scenic spot were mainly forest land and cultivated land. The project was intend to occupy the forest, bushes and grasses land and cultivated land, with an area of $0.14 \mathrm{hm}^{2}$, $0.09 \mathrm{hm}^{2}$ and $0.11 \mathrm{hm}^{2}$ respectively. Then the permanent occupation area was all transferred to the building land. Thus, the building and other land within the Tangya River Scenic spot evaluation scope would increase by $0.34 \mathrm{hm}^{2}$ in total after the completion of project.

It can be seen from Table 2 that the land-use type of crossing section in Tangya River was mainly forest land, accounting for $64.09 \%$ of the whole evaluation section, indicating that the ecological environment of the crossing section was optimistic. From the perspective of transfer intensity, the transfer intensity of bushes and grasses land and cultivated land were both higher than 1, indicating that the transfer intensity of bushes and grasses land and cultivated land were both greater than that of the whole evaluation area. From the perspective of dynamic attitude of a certain land-use type, the land-use transfer matrix shown that the dynamic change of forest land, bushes and grasses land, cultivated land were all not large, and the biggest change was happened in building land $\left(K_{T}=0.40 \%\right)$, which may be due to the newly transferred land-use types of the project were all changed into building land, leading to a huge dynamic change of building and other land finally.

Table 2 Land-use transfer matrix of Tangya River scenic spot Unit:hm²

\begin{tabular}{|c|c|c|c|c|c|c|c|c|c|}
\hline $\begin{array}{c}\text { Type of } \\
\text { land-use }\end{array}$ & Forestland & $\begin{array}{c}\text { Bushes } \\
\text { and } \\
\text { grasses }\end{array}$ & $\begin{array}{c}\text { Cultivated } \\
\text { land }\end{array}$ & Water & $\begin{array}{c}\text { Building } \\
\text { and other } \\
\text { land }\end{array}$ & Total & $\begin{array}{c}\text { Percent } \\
/ \%\end{array}$ & $\begin{array}{c}\text { Roll } \\
\text { out }\end{array}$ & $R_{T}$ \\
\hline Forestland & 1606.92 & 0 & 0 & 0 & 0.14 & 1607.06 & 64.09 & 0.14 & 0.64 \\
\hline $\begin{array}{c}\text { Bushes and } \\
\text { grasses }\end{array}$ & 0 & 657.51 & 0 & 0 & 0.09 & 657.60 & 26.23 & 0.09 & $1.01^{*}$ \\
\hline $\begin{array}{c}\text { Cultivated } \\
\text { land }\end{array}$ & 0 & 0 & 135.70 & 0 & 0.11 & 135.81 & 5.41 & 0.11 & $5.98^{*}$ \\
\hline Water & 0 & 0 & 0 & 22.66 & 0 & 22.66 & 0.90 & 0 & 0 \\
\hline $\begin{array}{c}\text { Building } \\
\text { and other } \\
\text { land }\end{array}$ & 0 & 0 & 0 & 0 & 84.19 & 84.19 & 3.36 & 0 & 0 \\
\hline Total & 1606.92 & 657.51 & 135.70 & 22.66 & 84.52 & 2507.32 & 100 & 0.34 & $/$ \\
\hline Percent/\% & 64.09 & 26.22 & 5.41 & 0.90 & 3.37 & 100 & $/$ & $/$ & $/$ \\
\hline
\end{tabular}




\begin{tabular}{|c|c|c|c|c|c|c|c|c|c|}
\hline $\begin{array}{c}\text { Type of } \\
\text { land-use }\end{array}$ & Forestland & $\begin{array}{c}\text { Bushes } \\
\text { and } \\
\text { grasses }\end{array}$ & $\begin{array}{c}\text { Cultivated } \\
\text { land }\end{array}$ & Water & $\begin{array}{c}\text { Building } \\
\text { and other } \\
\text { land }\end{array}$ & Total & $\begin{array}{c}\text { Percent } \\
/ \%\end{array}$ & $\begin{array}{c}\text { Roll } \\
\text { out }\end{array}$ & $R_{T}$ \\
\hline Roll in & 0.14 & 0.09 & 0.11 & 0 & 0.34 & $/$ & $/$ & $/$ & $/$ \\
\hline $\begin{array}{c}\text { Net change } \\
\text { in area }\end{array}$ & -0.14 & -0.09 & -0.11 & 0 & +0.34 & $/$ & $/$ & $/$ & $/$ \\
\hline$K_{T} / \%$ & -0.009 & -0.014 & -0.081 & 0 & 0.40 & $/$ & $/$ & $/$ & $/$ \\
\hline
\end{tabular}

(Note: * indicated that the transfer intensity of a certain type land was greater than that of total land-use.)

\subsection{Land-use transfer matrix of Three Gorges Scenic spot}

The results of land-use transfer matrix in the Three Gorges Scenic were shown in Table 3. The project was intended to occupy an area of $0.22 \mathrm{hm}^{2}$ permanently, the land-use types of evaluation area in Three Gorges Scenic were mainly forest land, Bushes and grasses, cultivated land. The project was intend to occupy the forest, bushes and grasses land, cultivated land permanently, with an area of $0.08 \mathrm{hm}^{2}, 0.02 \mathrm{hm}^{2}$ and $0.12 \mathrm{hm}^{2}$ respectively. The permanent occupied area was all transferred to the building land. Thus, the land-use type of building and other land within the Three Gorges Scenic evaluation scope would increase by $0.22 \mathrm{hm}^{2}$ in total after the completion of project.

It can be seen from Table 3 that the proportion of forestland, Bushes and grasses, cultivated land and building and other land in the crossing section of Three Gorges Scenic were quite, which indicated that there was a large human disturbance in the section. From the perspective of transfer intensity, the transfer intensity of forestland and cultivated land were both higher than 1 , indicating that the transfer intensity of forestland and cultivated land were both greater than that of the whole evaluation area. From the perspective of dynamic attitude of a certain land-use type, the land-use transfer matrix shown that the dynamic change of forest land, bushes and grasses land, cultivated land were all not high, which were all lower than the dynamic change of building $\operatorname{land}\left(K_{T}=0.031 \%\right)$. This may be due to the fact that all the newly transferred land types have been converted into building land, and the initial area of the building land within the area of evaluation was very small, which lead to a relatively large dynamic change of building land eventually.

Table 3 Land-use transfer matrix of Three Gorges Scenic spot Unit:hm²

\begin{tabular}{|c|c|c|c|c|c|c|c|c|c|}
\hline $\begin{array}{c}\text { Type of } \\
\text { land-use }\end{array}$ & Forestland & $\begin{array}{c}\text { Bushes } \\
\text { and } \\
\text { grasses }\end{array}$ & $\begin{array}{c}\text { Cultivated } \\
\text { land }\end{array}$ & water & $\begin{array}{c}\text { Building } \\
\text { and other } \\
\text { land }\end{array}$ & Total & $\begin{array}{c}\text { Percent } \\
/ \%\end{array}$ & $\begin{array}{c}\text { Roll } \\
\text { out }\end{array}$ & $R_{T}$ \\
\hline Forestland & 773.26 & 0 & 0 & 0 & 0.08 & 773.34 & 24.39 & 0.08 & $1.49 *$ \\
\hline $\begin{array}{c}\text { Bushes and } \\
\text { grasses }\end{array}$ & 0 & 768.81 & 0 & 0 & 0.02 & 768.83 & 24.25 & 0.02 & 0.37 \\
\hline $\begin{array}{c}\text { Cultivated } \\
\text { land }\end{array}$ & 0 & 0 & 780.06 & 0 & 0.12 & 780.18 & 24.60 & 0.12 & $2.22 *$ \\
\hline water & 0 & 0 & 0 & 149.58 & 0 & 149.58 & 4.71 & 0 & 0 \\
\hline $\begin{array}{c}\text { Building } \\
\text { and other } \\
\text { land }\end{array}$ & 0 & 0 & 0 & 0 & 699.13 & 699.13 & 22.05 & 0 & 0 \\
\hline Total & 773.26 & 768.81 & 780.06 & 149.58 & 699.35 & 3171.07 & 100 & 0.22 & $/$ \\
\hline $\begin{array}{c}\text { Percent } / \% \\
\text { Roll in }\end{array}$ & 24.28 & 24.24 & 24.60 & 4.72 & 22.05 & 100 & $/$ & $/$ & $/$ \\
\hline $\begin{array}{c}\text { Net change } \\
\text { in area }\end{array}$ & -0.08 & -0.02 & -0.12 & 0 & +0.22 & $/$ & $/$ & $/$ & $/$ \\
\hline KT/\% & -0.010 & -0.003 & -0.015 & 0 & 0.031 & $/$ & $/$ & $/$ & $/$ \\
\hline
\end{tabular}

(Note: * indicated that the transfer intensity of a certain type land was greater than that of total land-use.)

\section{Discussion}

To sum up, we estimated that the project would have little influence on building land after completion. The dynamic attitude $K_{T}$ of a certain land-use type can predict the tendency of land-use change in the future. The permanent occupation land of overhead transmission line would be converted to building land, thus it was expected that the project would have the greatest impact on building land. The results of the land-use transfer matrix showed that the dynamic attitude $K_{T}$ of building land-use in Tangya Rive Scenic and the Three Gorges Scenic Spot were $0.40 \%$ and $0.031 \%$ respectively, which were both 
low. The evaluation of the Three Gorges Scenic spot was larger, resulting in a lower $K_{T}$. Therefore, we predicted that the project would have little influence on the change of the proportion of building land after completion.

Among all the land-use types in the crossing section, it was estimated that the conversion intensity of cultivated land would be the largest. The results of the land-use transfer matrix showed that the cultivated land transfer intensity $R_{T}$ in Tangya Rive Scenic and the Three Gorges Scenic Spot was 5.98 and 2.22 respectively. The cultivated land transfer intensity values in both Tangya Rive Scenic and the three Gorges Scenic Spot were higher than 1, indicating that the cultivated land transfer intensities of the crossing section were much greater than that of the whole evaluation area. The intensity of cultivated land transfer in Tangya River scenic area was higher than $5\left(R_{T}>5\right)$, which indicated that the conversion intensity of cultivated land was significantly larger than that of the whole evaluation area. This may be due to the small initial area of cultivated land. The conversion intensity $R_{T}$ can quantitatively describe the multiple relationship between the conversion rate of a certain land type and the overall conversion rate, compare and analyze the regional differences of land use change. The larger the area occupied by the project, the smaller the initial area of a certain type land was, then the larger conversion intensity of a certain type land.

It was predicted that the project would have a slight effected on the land-use pattern and function of the evaluation area and the whole Scenic Spot. The overall ecological function and structure of the evaluation area and the whole Scenic Spot would not be affected. The permanent occupation area of overhead transmission line was mainly the cement hardening area of the four tower legs, which occupies a small permanent area. The results of land-use transfer matrix showed that the dynamic attitude of the project area to each land type were all small $\left(K_{T} \leq 0.40 \%\right)$, so we drew a conclusion that the construction of the project would not change the original land use pattern in the evaluation area.

\section{References}

1. SH. Liu. Introduce the necessity of power grid reconstruction and energy saving and consumption reduction in power grid construction, Science and Information Technology. Vol.117(20), 2018, pp.2906-2908.

2. HX. Zhang, YZ. Shi, PH. Wang. Pay attention to the problems of cross-regional power grid involving nature reserves in the grid construction project, Central China Electric Power. Vol.24(4), 2011, pp. 29-32.

3. T. Chen, XQ. Zhang, Y. Cai. Research on the impact of overhead transmission lines on land use transfer in nature reserves, Energy and Environmental Protection. Vol.34(3), 2020, pp.92-97

4. JY. Liu, ML. Liu, DF. Liu. Spatial pattern analysis of recent land use change in China, Science in China Series D. Vol.32(12), 2002, pp.1031-1043.
5. CY. He, PJ. Shi, J. Chen. Study on land use/cover change in Beijing area, Geographical Research. Vol.6, 2001, pp. 679-687.

6. LZ. Miao, Y. Jiang. Analysis of land use change and dynamic monitoring in Aksu river basin, Geoinformation Science. 2007, Vol.9(2), 2007, pp.124128.

7. R. Liu, DL. Zhu. Discussion on land use change information mining method based on transfer matrix, Resources Science. Vol.32(8), 2010, pp.1544-1550.

8. L. Xu, Y. Zhao. Used the Markov process to predict the change of land use pattern in Dongling district, Chinese Journal of Applied Ecology. Vol.4(3),1993, pp.272-277.

9. B. Zhao, B. Huang, YF.Zhong, Transfer learning with fully pretrained deep convolution networks for land-use classification, IEEE Geoscience and Remote Sensing Letters. Vol.26,2017, pp. 1-5.

10. LL. Wang, DJ. Yu, TY. Bai. Land use status survey based on RS and GIS. Geospatial information, Vol.7(6), 2009, pp.94-97.

11. D. Li, YF. Luo, YB. Meng. Research on Land Use Spatial Change Based on GIS, Modern surveying and mapping, Vol.42(2), 2019, pp:13-17.

12. ZR Zhou, JL. Huang, P. Zhou. Land use system transfer analysis method and its application, Journal of Subtropical Resources and Environment. Vol.7(4), 2012, pp.28-38 